\title{
Fifteen years of customer engagement research: a bibliometric and network analysis
}

Article

Accepted Version

Hollebeek, L. D., Sharma, T. G., Pandey, R., Sanyal, P. and Clark, M. K. (2021) Fifteen years of customer engagement research: a bibliometric and network analysis. Journal of Product \& Brand Management,. ISSN 1061-0421 doi: https://doi.org/10.1108/JPBM-01-2021-3301 Available at https://centaur.reading.ac.uk/98973/

It is advisable to refer to the publisher's version if you intend to cite from the work. See Guidance on citing.

To link to this article DOI: http://dx.doi.org/10.1108/JPBM-01-2021-3301

Publisher: Emerald Publishing Limited

All outputs in CentAUR are protected by Intellectual Property Rights law, including copyright law. Copyright and IPR is retained by the creators or other copyright holders. Terms and conditions for use of this material are defined in the End User Agreement.

www.reading.ac.uk/centaur 
Central Archive at the University of Reading

Reading's research outputs online 
Fifteen years of customer engagement research: A bibliometric- and network analysis

\title{
Please cite as:
}

Hollebeek, L., Sharma, T., Pandey, R., Sanjal, P., \& Clark, M. (2021). Fifteen Years of Customer Engagement Research: A Bibliometric- and Network Analysis, Journal of Product \& Brand Management, In Press.

\begin{abstract}
Purpose - In recent years, customer engagement (CE) with brands, which has been shown to yield enhanced firm sales, competitive advantage, and stock returns, has risen to occupy a prominent position in brand management research and practice. Correspondingly, scholars have explored CE's conceptualization, operationalization, and its nomological networks as informed by different theoretical perspectives. However, despite important advances, the intellectual structure of the overall corpus of $\mathrm{CE}$ research remains tenuous, as therefore explored in this paper.
\end{abstract}

Design/methodology/approach - Based on this gap, this study deploys bibliometric- and network analysis to map CE's literature-based landscape. Using bibliometric analysis, important CE-publishing journals, authors, and influential CE articles (2005-2020) are uncovered. Using network analysis, prominent CE themes are also unearthed.

Findings - The results document key CE-publishing journals and authors, and their respective contributions to the literature. Five $\mathrm{CE}$ themes are also identified, including $\mathrm{CE}$ Measurement/Methods, Online CE, CE's Value Co-creating Capacity, CE Conceptualization, and Customer/Consumer Brand Engagement. Further, an agenda for future CE research is provided based on the presented network analysis results.

Practical implications - The reported findings generate important implications for brand managers. For example, the identified critical role of online (vs. offline) CE offers a range of strategic opportunities, as outlined.

Originality/value - This paper offers a pioneering bibliometric- and network analysis of the $\mathrm{CE}$ literature, thus mapping the field. From the identified $\mathrm{CE}$ themes, important avenues for further CE research are also identified.

Keywords - Customer engagement; brand engagement; bibliometric analysis; network analysis.

Paper type - Review paper. 


\section{Introduction}

In the last decade, customer engagement (CE), defined as a customer's resource investment in his/her brand interactions (Kumar et al., 2019, p. 141), has evolved into an important brand management metric. While traditional metrics, including customer involvement or commitment offer important insight, they fall short in isolating the dynamics transpiring in customers' brand interactions, as does CE (Brodie et al., 2011). Correspondingly, CE has been heralded pivotal in fueling sales growth, referrals, competitive advantage, and stock returns, among others (e.g., Pansari and Kumar, 2017).

That is, CE research has gained momentum in recent years (e.g., So et al., 2014; Hollebeek et al., 2014), as illustrated by its inclusion in the Marketing Science Institute's Research Priorities since 2010 (e.g., MSI, 2010, 2020). Moreover, journals including the International Journal of Research in Marketing (2021), Journal of Service Research (2021, 2011, 2010), Journal of Business Research (2020), Journal of Service Management (2018), Journal of the Academy of Marketing Science (2017), Journal of Product \& Brand Management (2014), and the Journal of Consumer Psychology (2009) have published Special Issues on CE, revealing its rising star. In the emerging literature, authors have primarily addressed CE's conceptualization, measurement, nomological network, and/or its specific contextual applications (e.g., Van Doorn et al., 2010; Hollebeek et al., 2019).

However, despite the escalating interest in $\mathrm{CE}$, a dearth of literature maps the overall body of CE research to date (Pansari and Kumar, 2018; Ortiz et al., 2018), exposing an important need to chart the field. That is, despite CE's rapid surge, most published research takes a piecemeal approach by focusing on particular CE aspects or -subsets (e.g., its conceptualization, antecedents, or consequences), rather than taking a broader birds-eye view of the overall $\mathrm{CE}$ literature. In addition, given the different theoretical perspectives adopted for CE, the field is starting to suffer from theoretical fragmentation (Hollebeek et al., 2019), yielding a need to 
systematically map this flourishing literature stream (e.g., Barari et al., 2020; De Oliveira Santini et al., 2020; Marvi et al., 2021).

Based on these gaps, this paper reports on a bibliometric analysis that quantitatively explores CE's literature-based landscape, including its major themes (Merigó Lindahl et al., 2015; Gaski, 2020). While the extant literature features several papers that offer in-depth reviews of CE research, this paper differs from those as follows. First, adopting Sepulcri et al.'s (2020) approach, the presented bibliometric analyses quantitatively map the CE's literature's intellectual structure, as distinct from systematic literature reviews (e.g., So et al., 2020; Ng et al., 2020) or meta-analyses (e.g., De Oliveira Santini et al., 2020) that tend to explore particular, typically narrower research issues or -questions. The second difference is, by incorporating a range of CE-related keywords (e.g., customer/consumer brand engagement, etc., as detailed in section 3), the reported analyses extend beyond reviews limited to a single keyword (e.g., customer engagement).

This paper's contributions are as follows. First, it maps the CE literature's evolutionary path by quantifying, aggregating, and ranking important $\mathrm{CE}$ articles, their authors, journals, and themes (Braam et al., 1991a/b), thus charting CE's development over time. Given the field's increasingly fragmented nature (Hollebeek et al., 2019), comprehensive analyses that take stock of CE's current state and foretell its future are required. Addressing this gap, this paper reports on an in-depth bibliometric- and network analysis of the overall corpus of $\mathrm{CE}$ literature (2005-2020), thus offering broad insight into its intellectual structure.

As the paper's second contribution, a research agenda is derived from the network analysis results to guide future $\mathrm{CE}$ scholarship. That is, building on the identified $\mathrm{CE}$ themes, the paper outlines important opportunities for CE researchers in the coming years (see section 6.3). For example, as some of the derived themes (e.g., Online $C E$ ) are expected to continue evolving (e.g., as new innovations are launched; e.g., Huang and Rust, 2021; Singh et al., 2021; 
Hollebeek, Sprott, and Brady, 2021), how might specific innovations impact the identified CE themes?

The paper's remainder is organized as follows. Important CE literature is next reviewed in section 2 , followed by an outline of the adopted methodology in section 3 . Section 4 discusses the data analysis, followed by an overview of the results in section 5. The paper concludes with an outline of important implications that arise from the reported analyses work and an agenda for further research in section 6 .

\section{Literature review}

In the last decade, $\mathrm{CE}$ has received significant attention from marketing researchers (Harmeling et al., 2017). While early CE articles emerged around 2005 (e.g., Sawhney et al., 2005), the field started to take off from around the turn of the decade (e.g., Bowden, 2009; Van Doorn et al., 2010; Brodie et al., 2011). In this period, the 2010 and 2011 Special Issues of the Journal of Service Research offer significant CE milestones. For example, Van Doorn et al.'s (2010, p. 254) customer engagement behaviors, defined as "a customer's behavioral manifestation that have a brand- or firm focus, beyond purchase, resulting from motivational drivers," is widely adopted in subsequent research. Since then, CE research has spawned into a number of directions, including conceptual CE studies (e.g., Kumar et al., 2019), CE scale development work (e.g., Hollebeek et al., 2014), context-specific exploration of CE (e.g., So et al., 2016), and CE with brands, as facilitated by digital platforms (e.g., social media, artificial intelligence; e.g., Henkens et al., 2021; Eisingerich et al., 2021).

The literature review commenced by consulting early CE papers that appeared around 2005, as noted (e.g., Sawhney et al., 2005; Patterson et al., 2006), from which the field's evolutionary path was traced, revealing the following observations. First, CE's definition is widely debated. For example, Kumar et al. (2019, p. 141) define CE as “a customer's 
...volitional investment of focal operant resources (including cognitive, emotional, behavioral, and social knowledge/skills), and operand resources (e.g., equipment) in brand interactions" (Hollebeek et al., 2019, p. 166). However, Brodie et al. (2011, p. 260) view the concept as "a psychological state, which occurs by virtue of interactive customer experiences with a focal agent/object [commonly, a brand] within ... service relationships." Despite their differences, these conceptualizations share a focus on the customer's brand interactions that pervades the CE literature (e.g., Harmeling et al., 2017; Loureiro et al., 2017; Maslowska et al., 2016; Leckie et al., 2016; Calder et al., 2009).

Though CE can transpire with different objects (e.g., brands, products, firms), published CE research has typically adopted the brand as focal engagement object (Hollebeek, 2011a/b). That is, in CE, the engagement subject (i.e., (s)he, who engages) tends to be the customer, who most commonly engages with (a) brand(s) (e.g., Moliner et al., 2018; Loureiro et al., 2017; Hollebeek et al., 2014; Brodie et al., 2011). Some authors explicitly identify their focal engagement subject and -object (e.g., by using the term customer brand engagement; e.g., Merrilees, 2016; France et al., 2016). However, others leave either the focal engagement subject or -object implicit in their concept designation. For example, while the brand engagement concept reveals an implicit engagement subject (i.e., (s)he, who engages, is not specified; e.g., Sprott et al., 2009; Malhotra et al., 2013), customer engagement reflects an implicit engagement object (i.e., that, which the customer engages with, is not stated; e.g., Pansari and Kumar, 2017; Verhoef et al., 2010). However, even authors who do not specify their focal engagement object nevertheless predominantly study CE with brands (e.g., Harrigan et al., 2018; Harmeling et al., 2017; Brodie et al., 2011). That is, CE's typical engagement object discerned in the literature is the brand.

The second observation is that, though the terms customer- and consumer engagement are somewhat disparate, semantically, careful scrutiny of their respective articles reveals a high 
degree of similarity in their conceptual core (e.g., Hollebeek et al., 2019). For example, while customer engagement addresses the engagement subject of a brand's paying customers, consumer engagement's scope includes non-purchasing individuals (e.g., prospects), who may still impact the brand (e.g., by posting brand-related content on social media; e.g., Sharma et al. 2021; Azer and Alexander, 2020a; Hollebeek et al., 2014). That is, customer- and consumer engagement alike denote (potential) purchasers' resource investment in their brand interactions (e.g., Kumar et al., 2019; Hollebeek, 2019), leading us to view these as highly related concepts.

The third observation is that differing theoretical perspectives are used to frame CE (e.g., Rosado-Pinto and Loureiro, 2020). For example, while Hollebeek (2019) develops S-D logicinformed CE and Vivek et al. (2014) propose relationship marketing-informed CE, others draw on alternate perspectives, including social exchange theory (Hollebeek, 2011b) or congruity theory (Islam et al., 2018), to name a few, which tend to yield unique CE-based nomological networks. Given the debate surrounding CE's key theoretical associations, comprehensive CEbased analysis is required, as undertaken here through bibliometric- and network analysis.

The fourth observation is that though CE has been viewed from uni- and multi-dimensional perspectives, the latter dominates (e.g., Dessart et al., 2016; Schivinski et al., 2016; Calder et al., 2009). For example, Vivek et al. (2014) propose the CE facets of conscious attention, enthused participation, and social connection. Likewise, Hollebeek et al. (2014) suggest CE to comprise cognitive processing, affection, and activation. By contrast, other authors advocate uni-dimensional $\mathrm{CE}$, typically by highlighting its behavioral aspect (i.e., engagement behaviors) that reflect customers' brand-related activity (e.g., purchasing, helping other customers, writing reviews; Verleye et al., 2014; Van Doorn et al., 2010). Moreover, while some authors include the customer's in-role behaviors (e.g., purchase) in CE's scope (e.g., 
Hollebeek et al., 2019, 2020b), others limit CE's ambit to the customer's extra-role (e.g., customer citizenship) behaviors (e.g., Alexander et al., 2018; Vivek et al., 2014).

The fifth observation is that CE has been viewed from customer- (e.g., Brodie et al., 2011) and firm (e.g., Kumar et al., 2010) perspectives. Despite this duality of perspectives, most published studies center on the former (i.e., customer's) viewpoint (e.g., Beckers et al., 2018; Kumar et al., 2019) and its effect on the focal customer him/herself (e.g., CE's impact on the individual's brand loyalty/attachment; Loureiro et al., 2017; So et al., 2016; Leckie et al., 2016). However, more recently, authors including Fujita et al. (2020), Clark et al. (2020), and Azer and Alexander (2020b) distil CE's effect on other actors (e.g., fellow customers). Conversely, CE research taking a firm perspective highlights the concept's effect on the organization (e.g., by illuminating its capacity to build revenue, share-of-wallet, or profitability; Kumar et al., 2010; Meire et al., 2019), thus yielding important implications for brand managers.

The final observation is that, though CE has been studied in digital (online) and non-digital (offline) contexts, (empirical) research has tended to focus on one (vs. both) of these (e.g., Muntinga et al. (2011) or Algharabat et al. (2018) isolate CE's social media-based dynamics). However, given the rapid rate of innovation, $\mathrm{CE}$ is explored in an increasing array of digital contexts, including virtual/augmented/mixed reality-, gamification-, mobile app-, digital content marketing-, and artificial intelligence-based applications, to name a few (e.g., Huang and Rust, 2021; Leclercq et al., 2020; Hollebeek et al., 2020a; Hollebeek and Macky, 2019; Viswanathan et al., 2017). By contrast, conceptual CE research has typically derived more generic CE-based principles or insight that may hold across online- and offline CE manifestations (e.g., Hollebeek et al., 2019; Harmeling et al., 2017; Brodie et al., 2011; Kumar et al., 2010). Finally, offline CE has been examined in a range of sectors, including 
hospitality/tourism, public transport, nursing homes, gyms, hairdressing, retailing, and subsistence markets, among others (e.g., Loureiro and Sarmento, 2019; Grewal et al., 2017; Verleye et al., 2014; Akareem et al., 2021).

\section{Methodology}

Pritchard (1969) first introduced bibliometric analysis as "the application of mathematical and statistical methods to books and other means of communication." Bibliometric studies can involve either or both of the following methods (Osareh, 1996). The first, descriptive method involves studying a discipline by counting its major publications, authors, journals, institutions, and/or geographic regions. It uses quantification, aggregation, and ranking to understand the relative contributions of authors, journals, etc. to the topic area.

The second method uses citation analysis to establish (e.g., co-citation) relationships among publications, authors, journals, etc. The relationships are represented on two-dimensional maps (networks), which are then studied by using network analysis (Havemann and Scharnhorst, 2012). In these bibliographic networks, node-related differences (e.g., differing node sizes) offer insight into a scientific field's composition (Van Eck and Waltman, 2014). For example, closer inter-node proximity indicates greater levels of thematic resemblance. For CE research, these clustered (e.g., article) networks map its intellectual structure and identify its major themes (e.g., through co-citation analysis; Fetscherin and Heinrich, 2015; Vogel and Güttel, 2013; Cobo et al., 2011; Osareh, 1996; Van Eck and Waltman, 2014).

Two articles are said to be co-cited if they are jointly cited by a third article. In cocitation, earlier documents are linked if they are later cited together. Co-citation networks change over time, as new links are added (Zhao and Strotmann, 2008), revealing their dynamic nature. These networks are widely used to map scientific research (Chang et al., 2015), as therefore adopted in this paper. However, despite their benefits, co-citation networks also have 
limitations. For example, the articles in a cluster may extend beyond a single theme (e.g., as papers address multiple questions simultaneously; Havemann and Scharnhorst, 2012).

To conduct the analysis, the CE articles, journals, authors, etc. in the sample were first quantitatively aggregated and ranked. Network analysis was then deployed (by using reference co-citation) to identify major thematic CE clusters, in line with the stated contributions. Though several bibliometric software tools are available (e.g., Bibexcel, Gephi, GraphPad Prism; Fahimnia et al., 2015), R-based Bibliometrix was adopted in this study, given its elevated statistical capability and control (Aria and Cuccurullo, 2017; MacDonald, 2008). To perform the analyses, VOSViewer, a sophisticated bibliometric tool, was used (Van Eck and Waltman, 2014).

\section{Data analysis}

Using the Scopus database, a sample of 706 CE articles published in 2019 Australian Business Deans Council (ABDC) $\mathrm{A}^{*}$ - and A-ranked Marketing/Management journals was extracted in .csv and .bib format (Sepulcri et al., 2020; see Table I). Launched by Elsevier in 2004, Scopus contains more articles than any other academic database (Veloutsou and RuizMafe, 2020). Following these authors, the researchers relied on Scopus' quality standards to identify those articles that fit the selection criteria.

The ABDC (vs. other potential) rankings were selected, as they are based on extensive, periodic review by subject matter (i.e., discipline) experts, including in Marketing, which primarily houses the $\mathrm{CE}$ literature (ABDC, 2019). The ABDC rankings, which are known as an authoritative, inclusive, and widely adopted journal classification system (e.g., Svantesson et al., 2015; Hair et al., 2019; Grossmann et al., 2019), have also been successfully applied in prior bibliometric research (e.g., Hall, 2011; Donthu, 2020a), warranting their adoption in this study. The data comprised CE-based bibliographic-, citation-, author affiliation-, and reference information. To generate the dataset, the following steps were applied. 


\section{Table I about here}

Step 1: Keyword/database selection and search. The Scopus database was searched to collect eligible CE papers published from 2005 to 2020 based on their respective keywords. The authors developed an initial keyword listing that was discussed with a senior academic to ascertain keyword relevance (Veloutsou and Ruiz-Mafe, 2020). This process led to the following, final keyword listing that was searched in the database to generate the sample of CE articles: Customer engagement, consumer engagement, customer brand engagement, consumer brand engagement, customer engagement behavior/behaviour, user engagement, and online engagement. A publication start year of 2005 was selected, which features important early CE works (e.g., Sawhney et al., 2005), as outlined. The data collection cut-off date was June 26, 2020.

Step 2: Data collection. The above keywords were searched in the attained article titles, abstracts, and keywords. The search was limited to English papers published in ABDC (2019) A*- and A-ranked Marketing/Management journals, as noted, yielding a set of 706 articles published in the specified timeframe (see Figure 1). To conduct the analyses, the Scopus-based .csv and .bib data was converted into a more usable Microsoft Excel (.xlxs) format. The dataset was then manually checked against each of the eligible journals' tables-of-contents in the selected period to ensure that no articles had been missed.

\section{Figure 1 about here}

The bibliometric analyses were conducted in R's programming language that summarized the data and extracted CE article-, author-, and journal-related information. Each article's keywords and citations were also extracted. VOSViewer was next used to conduct the network analysis (Van Eck and Waltman, 2010). To visualize two-dimensional bibliographic networks, VOSViewer's distance-based approach uses inter-node distance to measure node 
relatedness, where smaller inter-node distances signify greater relatedness. Though network visualization analysis may use multidimensional scaling to locate the nodes, VOSViewer uses Visualization-of-Similarities (VOS) mapping to create two-dimensional bibliographic networks (Van Eck and Waltman, 2010; Waltman et al., 2010). On these maps, strongly (weakly)-related nodes appear close together (far from one another), respectively (Van Eck and Waltman, 2014). The main results are next outlined.

\section{Results}

\subsection{Major CE-publishing journals}

Each journal's impact was first reviewed by using its CE articles' frequency- and summed citation counts. The more $\mathrm{CE}$ articles are published in a journal, the greater its typical contribution to the field. Moreover, the more a journal's CE articles are cited, the greater its impact. Correspondingly, journal impact was determined by summating (a) its total number of published CE articles, and (b) its total CE-based citation count (Martens et al., 2016; Fetscherin and Heinrich, 2015; Fetscherin et al., 2019).

The top 25 CE-publishing journals by articles and citation count (shown in Table II) reveals the Journal of Business Research as the principal outlet for CE research to date (e.g., Brodie et al., 2013; Harrigan et al., 2018; Clark et al., 2020). Despite this, CE articles published in the Journal of Service Research (JSR) are most-cited (e.g., Bijmolt et al., 2010; Van Doorn et al., 2010). JSR's score is explained by its early (i.e., 2010-2011) Special Issues on CE, which have helped shape this then-nascent research area (e.g., Kumar et al., 2010; Brodie et al., 2011). Since then, the journal has also kept up a relatively steady stream of CE articles (e.g., Verleye et al., 2014; Chandler and Lusch, 2015; Donthu et al., 2020b), as illustrated by a further recent (Feb 2021) Special Issue on CE in Automated Service Interactions (e.g., Xiao and Kumar, 2021; Singh et al., 2021). Moreover, the Journal of Product \& Brand Management ranks third 
in terms of its published number of CE articles, and fourth in terms of its CE-based citations (e.g., France et al., 2016; Dessart et al., 2015; Hollebeek and Chen, 2014).

\section{Table II about here}

\subsection{Principal CE authors}

Individual scholars' contributions to the scholarly CE discourse were next assessed (Rey-Martí et al., 2016). Table III shows the number of CE articles published by the top $25 \mathrm{CE}$ authors. Its last column shows each author's fractionalized output (i.e., author output/number of co-authors), which is calculated by first taking the inverse of the number of authors for each paper to which an author contributed, and then summing the author's fractions.

\section{Table III about here}

The analyses reveal Dr Linda Hollebeek to lead in terms of her absolute and fractionalized CE output. This author's key contributions include the development of relevant sets of CE-based Fundamental Propositions (e.g., Hollebeek et al., 2019; Hollebeek and Macky, 2019; Brodie et al., 2011) and the composition of a 10-item CE scale (Hollebeek et al., 2014). The second author, Distinguished Professor V. Kumar, also entered the field of CE research relatively early (e.g., Kumar et al., 2010). Professor Kumar has published more CE articles (vs. Dr Hollebeek) in the top Marketing journals (e.g., Meire et al., 2019). Unlike Dr Hollebeek, who tends to focus on CE from a customer perspective, Professor Kumar variously takes a customer- (e.g., Kumar et al., 2019) and firm perspective of CE (e.g., Kumar et al., 2010). Professor Kumar is also a thought leader in exploring CE's interface with other stakeholders' engagement (e.g., Kumar and Pansari, 2016; Hollebeek et al., 2020b), and has pioneered the important notion of $C E$ value (e.g., Kumar et al., 2010), which has seen a substantive following (e.g., Carlson et al., 2017; Venkatesan et al., 2018; Hollebeek, Das, and Shukla, 2021). 


\subsection{Key CE articles}

The most influential (i.e., most-cited) CE articles that have shaped the domain's knowledge structure are next addressed. To do so, key articles' total citations were first examined. However, this approach favors older CE articles that have had comparatively more time to accumulate citations. To overcome this bias, $\mathrm{CE}$ articles were also compared based on their annual citation count, using 2020 as the reference year. That is, each paper's total citations were divided by its age (i.e., 2020 minus the article's publication year; see Table IV).

\section{Table IV about here}

The total citation results correspond to the intuitive notion that older papers tend to dominate this ranking, as outlined. Specifically, at 1,104 citations, Van Doorn et al.'s (2010) article tops this list (see Table IV). Advocating uni-dimensional (i.e., behavioral) CE, these authors coined the notion of Customer Engagement Behaviors, which has seen a wide following (e.g., Verleye et al., 2014; Groeger et al., 2016). At 1,041 citations (or 104.1 citations p.a., on average), the second article by Brodie et al. (2011) tops the listing of CE articles' annual citation counts. When this paper came out, broad, generalizable CE-based insight was limited, thus filling an important literature gap at the time. In 2019, Hollebeek et al. updated these authors' analyses by developing a revised set of Fundamental Propositions of CE based on S-D logic's updated (i.e., 2016) Foundational Premises (Vargo and Lusch, 2016).

\subsection{Major CE themes}

To identify important CE themes, reference co-citation analysis, which implies that two publications are cited together in an article (Small, 1973), was conducted. When two publications are frequently co-cited, they are likely to share some commonality (Benckendorff and Zehrer, 2013). Co-citation analysis was therefore used to discover clusters of co-cited 
article pairs, facilitating the development of insight into the intellectual structure of CE research (Small, 1978; Culnan, 1986).

The composed reference co-citation network maps the relative spatial positions of the most-cited CE papers, allowing the researchers to explore the relationships of influential $\mathrm{CE}$ scholars and -works (Benckendorff and Zehrer, 2013). To develop the co-citation network, articles with at least 15 citations were included, yielding a parsimonious network. Of the 44,787 cited references in the dataset, 98 articles met the 15-citation criterion (see the co-citation network shown in Figure 2). Those articles with the highest link-strengths in each cluster are also shown in Table V. In Figure 2, circle size reflects an article's citation count (i.e., with larger circles denoting more citations), while inter-circle distance reveals the degree of article similarity (i.e., closely [far]-positioned circles denote high [low] similarity; Van Nunen et al., 2018). In Figure 2, the most highly cited and most frequently co-cited CE papers are depicted by using fractional counting (Van Eck and Waltman, 2014; Leung et al., 2017; Bamel et al., 2020). The results reveal five clusters, shown in different colors, which represent key CE research themes, as discussed further below.

\section{Figure 2 and Table $\mathrm{V}$ about here}

The first cluster, titled $\boldsymbol{C E}$ Measurement/Methods (shown in red in Figure 2), comprises 32 articles. Several of the articles contained herein develop CE measurement scales (e.g., Sprott et al., 2009; So et al., 2014; Dessart et al., 2016; Schivinski et al., 2016), grounded in differing theoretical perspectives, as noted. For example, while Vivek et al.'s (2014) scale is framed by relationship marketing theory, Hollebeek et al. (2014) use S-D logic to inform the development of their instrument. Consequently, the articles contained in this cluster also propose unique CE-based nomological networks (e.g., Thakur, 2017; Dessart, 2017; So et al., 2014; Cheung et al., 2011; Rather et al., 2019, 2021). For example, though Calder et al. (2009) 
propose the CE consequence of brand usage, Harrigan et al. (2018) identify self-brand connection and brand loyalty intent as key CE outcomes. This cluster also contains travel-, tourism-, and hospitality-based CE research as an important contextual sub-niche, given the extensive number of empirical CE articles in this area (e.g., So et al., 2014, 2020; Parihar and Dawra, 2020; Loureiro et al., 2019; Itani et al., 2019).

In this cluster, structural equation modeling is widely used to explore CE's theoretical associations (e.g., Carvalho and Fernandes, 2018; Dessart et al., 2015; Leckie et al., 2016). However, other studies deploy such quantitative methods as experiments (e.g., Azer and Alexander, 2020a/b) or field experiments (e.g., Wolf et al., 2021; Eberhardt et al., 2021). Moreover, CE authors' toolkit also contains qualitative methods, including in-depth interviewing (e.g., Hollebeek, 2011b), netnography (e.g., Azer and Alexander, 2018), and case study research (e.g., Hanssen and Faegri, 2006; Breidbach et al., 2014).

The second cluster, titled Online $\boldsymbol{C E}$ (shown in dark green), includes 22 articles that explore CE with brands, as facilitated through digital platforms, including social media or online brand communities (e.g., Dessart et al., 2019; Read et al., 2019; Hollebeek et al., 2017; Hollebeek and Belk, 2021). Given their relative ease of data collection, online platforms offer a thriving CE research context (e.g., Brodie et al. 2013; Hammedi et al., 2015; Sashi, 2012). In this cluster, a range of theoretical issues has been explored, including the development of CEbased nomological networks (e.g., Thakur, 2019; Tuškej and Podnar, 2018), CE practice typologies (e.g., Hollebeek et al., 2017), and discussion of positive/negative CE (e.g., Bowden et al., 2017), among others. For example, Azer and Alexander (2018) address negatively valenced engagement in online brand communities as manifest through influencing behavior. This cluster also covers a growing range of digital platforms, including artificial intelligence-, Internet-of-Things-, blockchain-, and virtual reality-based applications, to name a few (e.g., 
Huang and Rust, 2021; Hollebeek, Sprott, and Brady, 2021; Prentice et al., 2019; Kunz et al., 2017; Venkatesan, 2017).

The third cluster, titled $\boldsymbol{C E}$ 's Value-Co-creating Capacity (blue) contains 22 articles that focus on CE's ability to co-create value (e.g., Fernandes and Remelhe, 2016; Jaakkola and Alexander, 2014; Hoyer et al., 2010). Given its cocreation focus, this cluster has predominantly used S-D logic, a key cocreation-embedding theory, to frame CE (e.g., Keeling et al., 2018; Hollebeek, 2019). Unsurprisingly, therefore, this cluster also contains Vargo and Lusch's (e.g., 2016) seminal work on S-D logic (e.g., Brodie et al., 2011; Rather et al., 2019). Despite its title, this cluster also features growing attention to CE's potential value codestructive effect (e.g., negative CE damaging a brand's reputation; Bowden et al., 2017; Hollebeek et al., 2020b; Hollebeek and Chen, 2014; Keeling et al., 2021). Moreover, this cluster reveals an inter-cluster link to the Online $C E$ cluster (e.g., authors examining the CE/cocreation interface in online (e.g., social media) settings; Fernandes and Remelhe, 2016; Hollebeek, 2019).

The fourth cluster, titled $\boldsymbol{C E}$ Conceptualization (light green/yellow), contains $17 \mathrm{CE}$ conceptualizing papers. Here, Van Doorn et al.'s (2010) Customer Engagement Behavior takes a central position, evidenced by its significant uptake in further research (e.g., Verleye et al., 2014; Groeger et al., 2016). In this cluster, Kumar et al.'s (2010) firm-based CE value and Brodie et al.'s (2011) CE also offer important milestones. This cluster thus incorporates a range of perspectives, including CE as viewed from customer- (e.g., Hollebeek et al., 2019) and firm standpoints (e.g., Kumar at al., 2010; Verhoef et al., 2010). It also comprises uni- (e.g., Van Doorn et al., 2010) and multi-dimensional CE conceptualizations (e.g., Hollebeek, 2011a), revealing its substantive breadth. As this cluster borders each of the others (see Figure 2), this reveals that a portion of the articles in each of the other four thematic clusters contain an important conceptual element, exposing further important inter-cluster links. For example, 
Jaakkola and Alexander (2014) theorize regarding CE's effect on value cocreation, thus transcending beyond cluster 3 to also incorporate aspects of cluster 4 .

The final (purple) cluster contains five articles addressing CE's theoretical subset of Customer Brand Engagement (CBE), which explicitly states the brand as focal engagement object (e.g., Leckie et al., 2016; Hollebeek, 2011a/b). CBE is identified to manifest differently for utilitarian (vs. hedonic) brands (e.g., Fernandes and Moreira, 2019; Hollebeek, 2013) and across tangible product (vs. service) brands (e.g., Behnam et al., 2021). Moreover, this cluster's proximity to the CE Measurement/Method (red) cluster, coupled with its relative distance from the $C E$ Conceptualization (i.e., light green/yellow) cluster, suggests the relative prevalence of methodological or empirical (vs. conceptual) CBE research (e.g., Hollebeek et al., 2014; Dessart et al., 2015). Important implications that arise from the reported analyses are next discussed.

\section{Discussion, implications, and limitations}

\subsection{Theoretical implications}

Despite the escalating research interest in CE, the field's intellectual structure remains nebulous, thus exposing an important research gap, as outlined. To address this gap, this study applied bibliometric- and network analysis to chart CE's intellectual structure, yielding the following theoretical implications.

As noted, Hollebeek et al. (2019, p. 173) point out that: “...the emergence of multiple, somewhat disparate, CE conceptualizations [and their associated nomological networks] ...is starting to engender fragmentation in CE research," which represents a growing concern. That is, highly context-specific findings that lack trans-contextual applicability run the risk of creating isolated pockets of (vs. generalizable) CE-based insight, which the present analyses have sought to address. That is, by identifying chief CE-publishing journals, -authors, and - 
articles, and deriving major $\mathrm{CE}$ themes, this paper makes an important contribution to the $\mathrm{CE}$ literature. Extending the derived insight, future CE authors are also advised to conduct theoretically- and methodologically rigorous research that aims to unify or consolidate increasingly disparate CE-based findings, thus halting the field's further fragmentation (e.g., MacInnis, 2005, 2011; Yadav, 2010). Specific avenues for future research, as structured by the identified CE themes, are offered in section 6.3.

\subsection{Managerial implications}

This paper also yields important implications for brand managers. First, the identified CE themes not only offer insight into the field's current developmental state, but also serve as a springboard for its future direction. For example, though Online $C E$ was identified as a major theme (e.g., Aksoy et al., 2013; Dessart et al., 2015), its counterpart of offline CE did not appear as a specific cluster. Consequently, the results suggest the prominence of online (vs. offline)

CE. Indeed, despite the rapid development of new platforms designed to engage customers (e.g., Hollebeek and Belk, 2021), relatively little remains known regarding their effectiveness or performance, sparking important managerial questions (e.g., what is the return-oninvestment or return-on-engagement of specific platforms through the customer journey? e.g., Gill et al., 2017). Managerially, this current blind-spot can offer strategic opportunities (e.g., for those brands that are able to create a first-mover advantage in this regard or leap-frog competitors).

As a second implication, several of the $\mathrm{CE}$ themes remain heavily conceptual (e.g., $C E$ Conceptualization), exposing their forming (vs. fully formed) state. Managers are thus advised to stay abreast of evolving scholarly CE research, as doing so will equip them with pivotal strategic insight or foresight. Correspondingly, practitioners are invited to study important CE trends and apply their learnings to the brands they manage. 


\subsection{Further research}

In this section, further research avenues are outlined. First, CE Measurement/Methods captures empirical or methodological CE-based advances, including scale development work or scrutiny of CE's nomological network (e.g., Vivek et al., 2014; Sprott et al., 2009), as outlined. This cluster is expected to face a stimulating future, given the pace of new (e.g., technology-driven) methodological advances, whether through big data-, neuro-tracking-, artificial intelligence-, augmented/virtual/mixed reality-, the Internet-of-Everything-, or quantum- or edge-computing developments, to name a few, thus facilitating CE's measurement, -monitoring, -cultivation, -design, or -dissolution, as required (e.g., Kunz et al., 2017; Bridger, 2017). Particularly in COVID-19-impacted marketplaces, these technologydriven methodological advances, many of which can be adopted during pandemic-imposed restrictions (e.g., social distancing/lockdown; Hollebeek et al., 2020c), are expected to increasingly feature in $\mathrm{CE}$ research in the coming years. Specific issues for further investigation include: How may empirical CE research evolve, as new (e.g., measurement) technology becomes available? What benefits and caveats do respective measurement methods incur (e.g., to what extent might (e.g., neurological) tracking devices invade respondent privacy?). Do specific new methodological- or measurement tools offer improved understanding of CE?

The second theme, Online $\boldsymbol{C E}$, centers on CE with brands, as facilitated by digital platforms (e.g., Heller et al., 2021; Tuškej and Podnar, 2018; Harrigan et al., 2018). This cluster is also expected to see a dynamic future. That is, as technology continues to evolve, the suite of engagement-facilitating technological platforms is anticipated to grow, yielding potentially revolutionary opportunities for customer/brand interactivity (e.g., Duggal, 2021). What is at stake here is not only the exploration of particular platforms' capacity to foster (minimize) positive (negative) CE (e.g., Clark et al., 2020), respectively, but also, assessments of platformfacilitated CE with brands and their long-term effects on consumer wellbeing (e.g., Kumar and 
Ramachandran, 2021; Eberhardt et al., 2021; Hollebeek and Belk, 2021). For example, to what extent might new technologies, such as 5G, self-tracking devices (e.g., FitBit), Internet-ofThings-, or blockchain applications (e.g., Wolf et al., 2021; Duggal, 2021) actually contribute to (vs. jeopardize) wellbeing? Which (if any) digital platforms might become obsolete, and how will this affect CE?

The third theme of $\boldsymbol{C E}$ 's Value-Co-creating Capacity highlights CE's capacity to yield cocreated or codestroyed value (e.g., Bowden et al., 2017; Merrilees, 2016), as noted, which can transpire through face-to-face or (e.g., pandemic-imposed) physically distant interactions (e.g., Ramaswamy and Ozcan, 2016; Hollebeek et al., 2020c). For example, as singletons initially remain distanced from their potential match in online dating, their fate is bound by the other's assessment of them (e.g., "swipe left/right"), even though they are yet to meet in person. Consequently, the CE literature requires a deeper understanding of the nature and extent of physically proximate (vs. distant) actors and their respective effects on CE's value-cocreating (vs. codestructive) capacity (e.g., Osei-Frimpong et al., 2018), thus linking to the second theme of Online CE. Moreover, Hollebeek et al. (2020b) point out engagement's differing role valuecreating intentionality: While customers will consciously engage in some interactions to cocreate value (e.g., socially responsible/eco-innovation interactions; Loureiro and Lopes, 2019), they might involuntarily invest their (e.g., mental) resources in others (e.g., cognitive dissonance-based brand assessments; Chen et al., 2018). As a result, a more thorough understanding is required of customers' voluntary (vs. less voluntary) engagement with brands and their respective impact on cocreated value (e.g., Roy et al., 2018; Hollebeek et al., 2018).

The fourth theme, CE Conceptualization, has been instrumental in establishing and delineating the field since its inception in the mid-naughties (e.g., Sawhney et al., 2005; Brodie et al., 2011), thus making a foundational contribution in its own right, while also fueling the other identified themes (e.g., Lin et al., 2019; Reinartz and Berkmann, 2018). Though CE's 
conceptual domain is progressively well understood, the level of debate surrounding its conceptualization is troubling (Hollebeek et al., 2019). What is therefore needed is a universally applicable conceptualization that offers a clear, generalizable understanding of CE. Moreover, a growing literature sub-stream explores the engagement of other stakeholders or actors, in addition to that of the customer (e.g., Mitchell and Clark, 2019; Alexander et al., 2018; Brodie et al., 2016), yielding important implications for multi-actor service systems (e.g., Zagalo, 2020). For example, a sound understanding of different stakeholders' engagement with a central brand and its broad, multi-actor-based nomological network is required (e.g., $\mathrm{Ng}$ et al., 2020; Hollebeek et al., 2020b). Sample research questions include: What are actor/stakeholder engagement's key drivers and outcomes? Which factors are important moderators in the proposed associations?

With five articles, the fifth and final theme, Customer Brand Engagement (CBE), is the smallest of the identified clusters (e.g., Leckie et al., 2016; Graffigna and Gambetti, 2015; Hollebeek, 2011a). Explicitly designating the engagement object of the brand, this cluster exhibits a significant link to the CE Measurement/Methods cluster, as noted, suggesting its relatively high level of empirical (vs. conceptual) research production. However, as stated, while some authors may not use the term "CBE," their typical engagement object still is the brand (e.g., Brodie et al., 2011; Kumar et al., 2019). In practice, this cluster is therefore expected to extend beyond its five identified articles. However, though CE with (a) brand(s) has received prior attention, insight regarding CE with different brand elements, as they exist in the broader brand hierarchy (Keller, 1998), remains tenuous. Keller (1998) views the brand hierarchy as an explicit ordering of brand elements, including the corporate brand, family brand, individual brand, and modifier or sub-band (i.e., designating item/model; Keller, 2014). Moreover, as brands are dynamic (vs. static) entities (Stern, 2006), how might a brand's evolving nature (e.g., as affected by innovation or electronic word-of-mouth) affect CE (e.g., 
Chu and Kim, 2011)? Additional questions for further exploration include: How might CE with brands differ from CE with other potential engagement objects (e.g., firms, brand communities, or commodities)? How can CBE be leveraged for optimal firm performance (e.g., sales, returnon-investment)?

\subsection{Limitations and conclusion}

Despite its contribution, this study is not free from limitations, thus generating additional research opportunities. First, though the study provides a snapshot of CE research up until June 26, 2020, the field is likely to continue developing, rendering a need for future or follow-up bibliometric- and network analysis of the CE literature. For example, given the identified theoretical overlap among several of the identified CE themes, it will be important to replicate the reported analyses in a few years from now, when $\mathrm{CE}$ research has evolved further, and to compare/contrast the emerging findings to those reported in this paper. In these future studies, alternate or complementary methods (e.g., correspondence analysis, multidimensional scaling) may also be used. Future research could also test the stability of the proposed cluster structure, which may be subject to change as new CE articles are published.

The second limitation is that the documented analyses are limited to the ABDC (2019) rankings, thus overlooking other potential journal ranking systems (e.g., the Association of Business Schools [ABS] or Excellence in Research [ERA] rankings), which may yield differing insight. Moreover, the analysis was limited to ABDC $\mathrm{A}^{*}$ - and A-ranked journals, thus excluding lower (e.g., B)-ranked journals, books, and conference papers. Therefore, further researchers may wish to conduct bibliometric- and network analyses of CE research based on other or multiple journal rankings and/or by including scientific works beyond journal articles alone.

The third limitation is that, though five thematic CE clusters were identified, many of the articles contained in the dataset reveal aspects of multiple clusters (vs. a single cluster), as 
noted, which represents an inherent limitation of co-citation analysis. For example, though Calder et al.'s (2009) scale development paper is pegged to the CE Measurement/Methods cluster, it also exhibits characteristics of Online $C E$, given its website context. Therefore, as CE research continues to develop, it should be monitored for any novel or changing patterns or themes (e.g., the emergence of new themes, thematic convergence).

In conclusion, this paper has charted the intellectual structure of the CE literature and identified its major themes. Based on these analyses, an agenda for further research was also presented. However, though this paper reports on a pioneering bibliometric- and network analysis of CE research, the dynamic nature of the field generates a need for its continued screening and mapping in the coming years, as outlined. 


\section{References}

ABDC - Australian Business Deans Council (2019). ABDC Journal Quality List. Accessed (Feb 20, 2021) at: https://abdc.edu.au/research/abdc-journal-list-2/.

Akareem, H., Ferdous, A., and Todd, M. (2021). Impact of patient portal behavioral engagement on subsistence consumers' wellbeing. International Journal of Research in Marketing, In press, DOI: https://doi.org/10.1016/j.ijresmar.2020.09.003.

Aksoy, L., Van Riel, A., Kandampully, J., Wirtz, J., Den Ambtman, A., Bloemer, J., ... and Canli, Z. (2013). Managing brands and customer engagement in online brand communities. Journal of Service Management, Vol. 24 No. 3, pp. 223-244.

Alexander, M., Jaakkola, E., and Hollebeek, L. (2018), Zooming out: Actor engagement beyond the dyadic. Journal of Service Management, Vol. 29 No. 3, pp. 333-351.

Algharabat, R., Rana, N., Dwivedi, Y., Alalwan, A., and Qasem, Z. (2018). The effect of telepresence, social presence and involvement on consumer brand engagement: An empirical study of non-profit organizations. Journal of Retailing and Consumer Services, Vol. 40 No. Jan, pp. 139-149.

Aria, M. and Cuccurullo, C. (2017). Bibliometrix: An R-tool for comprehensive science mapping analysis. Journal of Informetrics, Vol. 11 No. 4, pp. 959-975.

Azer, J., and Alexander, M. (2018). Conceptualizing negatively valenced influencing behavior: forms and triggers. Journal of Service Management, Vol. 29 No. 3, pp. 468-490.

Azer, J., and Alexander, M. (2020a). Negative customer engagement behaviour: The interplay of intensity and valence in online networks. Journal of Marketing Management, Vol. 36 No. 3-4, pp. 361-383.

Azer, J., and Alexander, M. (2020b). Direct and indirect negatively valenced engagement behavior. Journal of Services Marketing, Vol. 34 No. 7, pp. 967-981.

Bamel, U., Pandey, R., and Gupta, A. (2020). Safety climate: Systematic literature network analysis of 38 years (1980-2018) of research. Accident Analysis \& Prevention, Vol. 135 No. Feb, pp. 105387.

Barari, M., Ross, M., Thaichon, S., and Surachartkumtonkun, J. (2020). A meta-analysis of customer engagement behaviour. International Journal of Consumer Studies, In press, DOI: https://doi.org/10.1111/ijcs.12609.

Beckers, S., Van Doorn, J., and Verhoef, P. (2018). Good, better, engaged? The effect of companyinitiated customer engagement behavior on shareholder value. Journal of the Academy of Marketing Science, Vol. 46 No. 3, pp. 366-383.

Behnam, M., Hollebeek, L., Clark, M., and Farabi, R. (2021). Exploring customer engagement in the product vs. service context. Journal of Retailing \& Consumer Services, In press, DOI: https://doi.org/10.1016/j.jretconser.2021.102456.

Benckendorff, P. and Zehrer, A. (2013). A network analysis of tourism research. Annals of Tourism Research, Vol. 43 No. Oct, pp. 121-149.

Bijmolt, T., Leeflang, P., Block, F., Eisenbeiss, M., Hardie, B., Lemmens, A., and Saffert, P. (2010). Analytics for customer engagement. Journal of Service Research, Vol. 13 No. 3, pp. 341-356.

Bowden, J. (2009). Customer engagement: A framework for assessing customer-brand relationships: The case of the restaurant industry. Journal of Hospitality Marketing \& Management, Vol. 18 No. 6, pp. 574-596.

Bowden, J., Conduit, J., Hollebeek, L., Luoma-Aho, V., and Solem, B. (2017). Engagement valence duality and spillover effects in online brand communities. Journal of Service Theory and Practice, Vol. 27 No. 4, pp. 877-897.

Braam, R., Moed, H., and Van Raan, A. (1991a). Mapping of science by combined co-citation and word analysis, I: Structural aspects. Journal of the American Society for Information Science, Vol. 42 No. 4, pp. 233-251. 
Braam, R, Moed, H., \& Van Raan, A. (1991b). Mapping of science by combined co-citation and word analysis, II: Dynamical aspects. Journal of the American Society for Information Science, Vol. 42 No. 4, pp. 252-266.

Breidbach, C., Brodie, R., and Hollebeek, L. (2014). Beyond virtuality: From engagement platforms to engagement ecosystems. Managing Service Quality, Vol. 24 No. 6, pp. 592-611.

Bridger, D. (2017). Neuro Design: Neuromarketing Insights to Boost Engagement and Profitability. Kogan Page.

Brodie, R., Fehrer, J., Jaakkola, E., Conduit, J., and Hollebeek, L. (2016). From customer to actor engagement: Exploring a broadened conceptual domain. $45^{\text {th }}$ European Marketing Academy Conference, Oslo.

Brodie, R., Hollebeek, L., Jurić, B., and Ilić, A. (2011). Customer engagement: Conceptual domain, fundamental propositions, and implications for research in service marketing. Journal of Service Research, Vol. 14 No. 3, pp. 252-271.

Brodie, R., Ilić, A., Jurić, B., and Hollebeek, L. (2013). Consumer engagement in a virtual brand community: An exploratory analysis. Journal of Business Research, Vol. 66 No. 1, pp. 105114.

Calder, B., Malthouse, E., and Schaedel, U. (2009). An experimental study of the relationship between online engagement and advertising effectiveness. Journal of Interactive Marketing, Vol. 23 No. 4, pp. 321-331.

Carlson, J., De Vries, N., Rahman, M., and Taylor, A. (2017). Go with the flow: Engineering flow experiences for customer engagement value creation in branded social media environments. Journal of Brand Management, Vol. 24, pp. 334-348.

Carvalho, A. and Fernandes, T. (2018). Understanding customer brand engagement on virtual social communities: A comprehensive model of drivers, outcomes and moderators. Journal of Marketing Theory \& Practice, Vol. 26 No. 1-2, pp. 23-37.

Chandler, J. and Lusch, R. (2015). Service systems: A broadened framework and research agenda on value propositions, engagement, and service experience. Journal of Service Research, Vol. 18 No. 1, pp. 6-32.

Chang, Y., Huang, M., and Lin, C. (2015). Evolution of research subjects in library and information science based on keyword, bibliographical coupling, and co-citation analyses. Scientometrics, Vol. 105 No. 3, pp. 2071-2087.

Chen, H., Hoekstra-Atwood, L., and Donmez, B. (2018). Voluntary and involuntary distraction engagement: An exploratory study of individual differences. Human Factors, Vol. 60 No. 4, pp. 575-588.

Cheung, C., Lee, M., and Jin, X. (2011). Customer engagement in an online social platform: A conceptual model and scale development. ICIS 2011 Proceedings. Accessed (Feb 7, 2021) at: https://aisel.aisnet.org/icis2011/proceedings/onlinecommunity/8.

Chu, S. and Kim, Y. (2011). Determinants of consumer engagement in electronic word-of-mouth (eWOM) in social networking sites. International Journal of Advertising, Vol. 30 No. 1, pp. 47-75.

Clark, M., Lages, C., and Hollebeek, L. (2020). Friend or foe? Customer engagement's value-based effects on fellow customers and the firm. Journal of Business Research, Vol. 121, pp. 549556.

Cobo, M., López-Herrera, A., Herrera-Viedma, E., and Herrera, F. (2011). Science mapping software tools: Review, analysis, and cooperative study among tools. Journal of the American Society for Information Science and Technology, Vol. 62 No. 7, pp. 1382-1402.

Culnan, M. (1986). The intellectual development of management information systems 1972-1982: A co-citation analysis. Management Science, Vol. 32 No. 2, pp. 156-172. 
De Oliveira Santini, F., Ladeiral, W., Jr., Costa Pinto, D., Maurer Herter, M., Hoffmann Sampaio, C., and Babin, B. (2020). Customer engagement in social media: A framework and metaanalysis. Journal of the Academy of Marketing Science, Vol. 48, pp. 1211-1228.

Dessart, L. (2017). Social media engagement: A model of antecedents and relational outcomes. Journal of Marketing Management, Vol. 33 No. 5-6, pp. 375-399.

Dessart, L., Aldás-Manzano, J., and Veloutsou, C. (2019). Unveiling heterogeneous engagementbased loyalty in brand communities. European Journal of Marketing, Vol. 53 No. 9, pp. 18541881.

Dessart, L., Veloutsou, C., and Morgan-Thomas, A. (2015). Consumer engagement in online brand communities: A social media perspective. Journal of Product \& Brand Management, Vol. 24 No. 1, pp. 28-42.

Dessart, L., Veloutsou, C., and Morgan-Thomas (2016). Capturing consumer engagement: Duality, dimensionality, and measurement. Journal of Product \& Brand Management, Vol. 32 No. 56, pp. 399-426.

Ding, Y., Chowdhury, G., and Foo, S. (2001). Bibliometric cartography of information retrieval research by using co-word analysis. Information Processing \& Management, Vol. 37 No. 6, pp. 817-842.

Donthu, N., Reinartz, W., Kumar, S., and Pattnaik, D. (2020a). A retrospective review of the first 35 years of the International Journal of Research in Marketing. International Journal of Research in Marketing, In press, DOI: https://doi.org/10.1016/j.ijresmar.2020.10.006.

Donthu, N., Gremler, D., Kumar, S., and Pattnaik, D. (2020b). Mapping of Journal of Service Research themes: A 22-year review. Journal of Service Research, In press, DOI: https://doi.org/10.1177/1094670520977672.

Duggal, N. (2021). Top 9 New Technology Trends for 2021. Accessed Feb 22, 2021 at: https://www.simplilearn.com/top-technology-trends-and-jobs-article.

Eberhardt, W., Brüggen, E., Post, T., and Hoet, C. (2021). Engagement behavior and financial wellbeing: The effect of message framing in online pension communication. International Journal of Research in Marketing, In press, DOI: https://doi.org/10.1016/j.ijresmar.2020.11.002.

Eisingerich, A., Lin, Y. and Doong, H. (2021). Avatar design of virtual salespeople: Mitigation of recommendation conflicts. Journal of Service Research, DOI: https://doi.org/10.1177/1094670520964872.

Fahimnia, B., Sarkis, J., and Davarzani, H. (2015). Green supply chain management: A review and bibliometric analysis. International Journal of Production Economics, Vol. 162, pp. 101-114.

Fernandes, T. and Moreira, M. (2019). Consumer brand engagement, satisfaction and brand loyalty: A comparative study between functional and emotional brand relationships. Journal of Product \& Brand Management, Vol. 28 No. 2, pp. 274-286.

Fernandes, T. and Remelhe, P. (2016). How to engage customers in co-creation: Customers' motivations for collaborative innovation. Journal of Strategic Marketing, Vol. 24 No. 3-4, pp. 311-326.

Fetscherin, M., Guzmán, F., Veloutsou, C., and Cayolla, R. (2019). Latest research on brand relationships: introduction to the special issue. Journal of Product \& Brand Management, Vol. 29 No. 5, pp. 655-673.

Fetscherin, M. and Heinrich, D. (2015). Consumer brand relationships research: A bibliometric citation meta-analysis. Journal of Business Research, Vol. 68 No. 2, pp. 380-390.

Marvi, R., Beek, L., and Foroudi, P. (2021). Evolving knowledge foundation in customer engagement. Working paper.

France, C., Merrilees, B., and Miller, D. (2016). An integrated model of customer-brand engagement: Drivers and consequences. Journal of Brand Management, Vol. 23, pp. 119-136. 
Fujita, M., Harrigan, P., Soutar, G., Kumar Roy, S., and Roy, R. (2020). Enhancing memberinstitution relationships through social media: The role of other-user engagement behavior and similarity perceptions. Journal of Business Research, Vol. 121, pp. 642-654.

Gaski, J. (2020). A history of brand misdefinition - with corresponding implications for mismeasurement and incoherent brand theory. Journal of Product \& Brand Management, Vol. 29 No. 4, pp. 517-530.

Gill, M., Sridhar, S., and Grewal, R. (2017). Return on engagement initiatives: A study of a businessto-business mobile app. Journal of Marketing, Vol. 81 No. 4, pp. 45-66.

Graffigna, G. and Gambetti, R. (2015). Grounding consumer-brand engagement: A field-driven conceptualization. International Journal of Market Research, Vol. 57 No. 4, pp. 605-630.

Grewal, D., Roggeveen, A. L., Sisodia, R., and Nordfält, J. (2017). Enhancing customer engagement through consciousness. Journal of Retailing, Vol. 93 No. 1, pp. 55-64.

Groeger, L., Moroko, L., and Hollebeek, L. (2016). Capturing value from non-paying consumers' engagement behaviours: Field evidence and development of a theoretical model. Journal of Strategic Marketing, Vol. 24 No. 3-4, pp. 190-209.

Grossmann, A., Mooney, L., and Dugan, M. (2019). Inclusion fairness in accounting, finance, and management: An investigation of A-star publications on the ABDC journal list. Journal of Business Research, Vol. 95 No. Feb, pp. 232-241.

Hair, J., Wood, B., and Sharland, A. (2019). Toward a better understanding of the Australian Business Deans Council (ABDC) list and its rankings. International Journal of Educational Management, Vol. 33 No. 4, pp. 644-650.

Hall, C. (2011). Publish and perish? Bibliometric analysis, journal ranking and the assessment of research quality in tourism. Tourism Management, Vol. 32 No. 1, pp. 16-27.

Hammedi, W., Kandampully, J., Zhang, T., and Bouquiaux, L. (2015). Online customer engagement: Creating social environments through brand community constellations. Journal of Service Management, Vol. 26 No. 5, pp. 777-806.

Hanssen, G. and Faegri, T. (2006). Agile customer engagement: A longitudinal qualitative case study. Proceedings of the 2006 ACM/IEEE International Symposium on Empirical Software Engineering (Sep), pp. 164-173 (DOI: https://doi.org/10.1145/1159733.1159759).

Harmeling, C., Moffett, J. W., Arnold, M., and Carlson, B. (2017). Toward a theory of customer engagement marketing. Journal of the Academy of Marketing Science, Vol. 45 No. 3, pp. 312335.

Harrigan, P., Evers, U., Miles, M., and Daly, T. (2018). Customer engagement and the relationship between involvement, engagement, self-brand connection and brand usage intent. Journal of Business Research, Vol. 88, pp. 388-396.

Havemann, F. and Scharnhorst, A. (2012). Bibliometric networks. Preprint ArXiv:1212.5211.

Heller, J., Chylinski, M., De Ruyter, K., Keeling, D., Hilken, T., and Mahr, D. (2020). Tangible service automation: Decomposing the technology-enabled engagement process (TEEP) for augmented reality. Journal of Service Research, DOI: https://doi.org/10.1177/1094670520933692.

Henkens, B., Verleye, K., and Larivière, B. (2021). The smarter, the better?! Customer well-being, engagement, and perceptions in smart service systems. International Journal of Research in Marketing, In press, DOI: https://doi.org/10.1016/j.ijresmar.2020.09.006.

Hollebeek, L. (2011a). Demystifying customer brand engagement: Exploring the loyalty nexus. Journal of Marketing Management, Vol. 27 No. 7-8, pp. 785-807.

Hollebeek, L. (2011b). Exploring customer brand engagement: Definition and themes. Journal of Strategic Marketing, Vol. 19 No. 7, pp. 555-573.

Hollebeek, L. (2013). The customer engagement/value interface: An exploratory investigation. Australasian Marketing Journal, Vol. 21 No. 1, pp. 17-24. 
Hollebeek, L. (2019). Developing business customer engagement through social media engagement-platforms: An integrative S-D logic/RBV-informed model. Industrial Marketing Management, Vol. 81 No. Aug, pp. 89-98.

Hollebeek, L., Andreassen, T., Smith, D., Grönquist, Karahasanovic, A., and Márquez, A. (2018). Service innovation actor engagement: An integrative model. Journal of Services Marketing, Vol. 32 No. 1, pp. 95-100.

Hollebeek, L. and Belk, R.W. (2021). Consumers' technology-facilitated brand engagement and wellbeing: Positivist TAM/PERMA- vs. Consumer Culture Theory perspectives. International Journal of Research in Marketing, In press, DOI: https://doi.org/10.1016/j.ijresmar.2021.03.001.

Hollebeek, L. and Chen, T. (2014). Exploring positively- vs. negatively-valenced brand engagement: A conceptual model. Journal of Product \& Brand Management, Vol. 23 No. 1, pp. 62-74.

Hollebeek, L., Clark, M., Andreassen, T., Sigurdsson, V., and Smith, D. (2020a). Virtual reality through the customer journey: Framework and propositions. Journal of Retailing and Consumer Services, Vol. 55, No. July, 102056.

Hollebeek, L., Das, K., and Shukla, Y. (2021). Game on! How gamified loyalty programs boost customer engagement value. International Journal of Information Management, In press, DOI: https://doi.org/10.1016/j.ijinfomgt.2021.102308.

Hollebeek, L., Glynn, M., and Brodie, R. (2014). Consumer brand engagement in social media: Conceptualization, scale development and validation. Journal of Interactive Marketing, Vol. 28 No. 2, pp. 149-165.

Hollebeek, L., Jurić, B., and Tang, W. (2017). Virtual brand community engagement practices: A refined typology and model. Journal of Services Marketing, Vol. 31 No. 3, pp. 204-217.

Hollebeek, L., Kumar, V., and Srivastava, R.K. (2020b). From customer-, to actor-, to stakeholder engagement: Taking stock, conceptualization, and future directions, Journal of Service Research, DOI: 10.1177/1094670520977680.

Hollebeek, L. and Macky, K. (2019). Digital content marketing's role in fostering consumer engagement, trust, and value: Framework, fundamental propositions, and implications. Journal of Interactive Marketing, Vol. 45 No. 1, pp. 27-41.

Hollebeek, L., Smith, D., Kasabov, E., Hammedi, W., Warlow, A., and Clark, M. (2020c). Customer brand engagement during service lockdown. Journal of Services Marketing, In press, DOI: 10.1108/JSM-05-2020-0199.

Hollebeek, L., Sprott, D., and Brady, M. (2021). Rise of the machines? Customer engagement in automated service interactions. Journal of Service Research, Vol. 24 No. 1, pp. 3-8.

Hollebeek, L., Srivastava, R.K., and Chen, T. (2019). S-D logic-informed customer engagement: Integrative framework, revised fundamental propositions, and application to CRM. Journal of the Academy of Marketing Science, Vol. 47 No. 1, pp. 161-185.

Hoyer, W., Chandy, R., Dorotic, M., Krafft, M., and Singh, S. (2010). Consumer cocreation in new product development. Journal of Service Research, Vol. 13 No. 3, pp. 283-296.

Huang, M.H. and Rust, R. (2021). Engaged to a robot? The role of AI in service. Journal of Service Research, Vol. 24 No. 1, pp. 30-41.

Islam, J., Rahman, Z. and Beck, L. (2018). Consumer engagement in online brand communities: A solicitation of congruity theory. Internet Research, Vol. 28 No. 1, pp. 23-45.

Itani, O., Kassar, A., and Loureiro, S. (2019). Value get, value give: The relationships among perceived value, relationship quality, customer engagement, and value consciousness. International Journal of Hospitality Management, Vol. 80, pp. 78-90.

Jaakkola, E. and Alexander, M. (2014). The role of customer engagement behavior in value cocreation: A service system perspective. Journal of Service Research, Vol. 17 No. 3, pp. 247261. 
Keeling, D., Keeling, K., De Ruyter, K., and Laing, A. (2021). How value co-creation and codestruction unfolds: A longitudinal perspective on dialogic engagement in health services interactions. Journal of the Academy of Marketing Science, Vol. 49 No. 2, pp. 236-257.

Keeling, D., Laing, A., and De Ruyter, K. (2018). Evolving roles and structures of triadic engagement in healthcare. Journal of Service Management, Vol. 29 No. 3, pp. 352-377.

Keller, K.L. (1998). Building, Measuring and Managing Brand Equity. Upper Saddle River: Prentice Hall.

Keller, K.L. (2014). Designing and implementing brand architecture strategies. Journal of Brand Management, Vol. 21, pp. 702-715.

Kumar, V., Aksoy, L., Donkers, B., Venkatesan, R., Wiesel, T., and Tillmanns, S. (2010). Undervalued or overvalued customers: Capturing total customer engagement value. Journal of Service Research, Vol. 13 No. 3, pp. 297-310.

Kumar, V. and Pansari, A. (2016). Competitive advantage through engagement. Journal of Marketing Research, Vol. 53 No. 4, pp. 497-514.

Kumar, V., Rajan, B., Gupta, S., and Dalla Pozza, I. (2019). Customer engagement in service. Journal of the Academy of Marketing Science, Vol. 47 No. 1, pp. 138-160.

Kumar, V. and Ramachandran, D. (2020). Developing firms' growth approaches as a multidimensional decision to enhance key stakeholders' wellbeing. International Journal of Research in Marketing, In press, DOI: https://doi.org/10.1016/j.ijresmar.2020.09.004.

Kunz, W., Aksoy, L., Bart, Y., Heinonen, K., Kabadayi, S., Ordenes, F., Sigla, M., Diaz, D., and Theodoulis, B. (2017). Customer engagement in a big data world. Journal of Services Marketing, Vol. 31 No. 2, pp. 161-171.

Leckie, C., Nayadzayo, M., and Johnson, L. (2016). Antecedents of consumer brand engagement and brand loyalty. Journal of Marketing Management, Vol. 32 No. 5-6, pp. 558-578.

Leclercq, T., Hammedi, W., Poncin, I., Kullak, A., and Hollebeek, L. (2020). When gamification backfires: The impact of perceived justice on online community contributions. Journal of Marketing Management, Vol. 36 No. 5-6, pp. 550-577.

Leung, X., Sun, J., and Bai, B. (2017). Bibliometrics of social media research: A co-citation and coword analysis. International Journal of Hospitality Management, Vol. 66 No. Sep, pp. 35-45.

Lin, M., Miao, L., Wei, W., and Moon, H. (2019). Peer engagement behaviors: Conceptualization and research directions. Journal of Service Research, Vol. 22 No. 4, pp. 388-403.

Loureiro, S., Gorgus, T., and Kaufmann, H. (2017). Antecedents and outcomes of online brand engagement: The role of brand love on enhancing electronic word-of-mouth. Online Information Review, Vol. 41 No. 7, pp. 985-1005.

Loureiro, S. and Lopes, J. (2019). How corporate social responsibility initiatives in social media affect awareness and customer engagement. Journal of Promotion Management. Vol. 25 No. 3, pp. 419-438.

Loureiro, S. and Sarmento, E. (2019). Place attachment and tourist engagement of major visitor attractions in Lisbon. Tourism and Hospitality Research, Vol. 19 No. 3, pp. 368-381.

MacDonald, J. (2008). Using $R$ for Data Analysis and Graphics: Introduction, Code and Commentary. Australian National University.

MacInnis, D. (2011). A framework for conceptual contributions in marketing. Journal of Marketing, Vol. 75 No. Jul, pp. 136-154.

MacInnis, D. (2005). Them versus us: Woes on the bifurcation of the academic marketing discipline. In: Marketing Renaissance: Opportunities and Imperatives for Improving Marketing Thought, Practice, and Infrastructure. Journal of Marketing, Vol. 69 No. Oct, pp. 14-16.

Malhotra, A., Malhotra, C., and See, A. (2013). How to create brand engagement on Facebook. MIT Sloan Management Review, Vol. 54 No. 2, pp. 18-20. 
Martens, C., Lacerda, F., Belfort, A., and De Freitas, H. (2016). Research on entrepreneurial orientation: Current status and future agenda. International Journal of Entrepreneurial Behavior \& Research, Vol. 22 No. 4, pp. 556-583.

Maslowska, E., Malthouse, E., and Collinger, T. (2016). The customer engagement ecosystem. Journal of Marketing Management, Vol. 32 No. 5-6, pp. 469-501.

Meire, M., Hewett, K., Ballings, M., Kumar, V., and Van Den Poel, D. (2019). The role of marketergenerated content in customer engagement marketing. Journal of Marketing, Vol. 83 No. 6, pp. 21-42.

Merigó Lindahl, J. M., Mas-Tur, A., Roig-Tierno, N., and Ribeiro-Soriano, D. (2015). A bibliometric overview of the Journal of Business Research between 1973-2014. Journal of Business Research, Vol. 68 No. 12, pp. 2645-2653.

Merrilees, B. (2016). Interactive brand experience pathways to customer-brand engagement and value co-creation. Journal of Product \& Brand Management, Vol. 25 No. 5, pp. 402-408.

Mitchell, S. and Clark, M. (2019). Reconceptualising product life-cycle theory as stakeholder engagement with non-profit organisations. Journal of Marketing Management, Vol. 35 No. 12, pp. 13-39.

Moliner, M., Monferrer-Tirado, D., and Estrada-Guillén, M. (2018). Consequences of customer engagement and customer self-brand connection. Journal of Services Marketing, Vol. 32 No. 4, pp. 387-399.

MSI - Marketing Science Institute (2010). Research Priorities 2010-2012. Accessed (Mar 11, 2021) at: http://image.sciencenet.cn/olddata/kexue.com.cn/upload/blog/file/2010/9/201091515178616316.pdf.

MSI - Marketing Science Institute (2020). Research Priorities 2020-2022. Accessed (Feb 7, 2021) at: https://www.msi.org/wp-content/uploads/2020/06/MSI_RP20-22.pdf.

Muntinga, D., Moorman, M., and Smit, E. (2011). Introducing COBRAs: Exploring motivations for brand-related social media use. International Journal of Advertising, Vol. 30 No. 1, pp. 13-46.

$\mathrm{Ng}$, S., Sweeney, J., and Plewa, C. (2020). Customer engagement: A systematic review and future research priorities. Australasian Marketing Journal, Vol 28 No. 4, pp. 235-252.

Ortiz, C., Vargas Barraza, J., and López, A. (2018). Engagement: Bibliometric analysis. Nova Scientia, Vol. 10, pp. 524-551.

Osareh, F. (1996). Bibliometrics, citation analysis and co-citation analysis: A review of literature I. Libri, Vol. 46 No. 3, pp. 149-158.

Osei-Frimpong, K. and MacLean, G. (2018). Examining online social brand engagement: A social presence theory perspective. Technological Forecasting and Social Change, Vol. 128 No. March, pp. 10-21.

Pansari, A. and Kumar, V. (2017). Customer engagement: The construct, antecedents, and consequences. Journal of the Academy of Marketing Science, Vol. 45 No. 3, pp. 294-311.

Pansari, A. and Kumar, V. (2018). Customer engagement marketing. In: R. Palmatier, V. Kumar, \& C. Harmeling (Eds.), Customer Engagement Marketing. Springer, pp. 1-27.

Parihar, P. and Dawra, J. (2020). The role of customer engagement in travel services. Journal of Product \& Brand Management, Vol. 29 No. 7, pp. 899-911.

Patterson, P., Yu, T., and D Ruyter, K. (2006). Understanding customer engagement in services. Australia-New Zealand Marketing Academy Conference.

Prentice, C., Wang, X., and Loureiro, S. (2019). The influence of brand experience and service quality on customer engagement. Journal of Retailing and Consumer Services, Vol. 50 No. Sep, pp. 50-59.

Pritchard, A. (1969). Statistical bibliography or bibliometrics. Journal of Documentation, Vol. 25 No. 4, pp. 348-349.

Ramaswamy, V. and Ozcan, K. (2016). Brand value co-creation in a digitalized world: An integrative framework and research implications. International Journal of Research in Marketing, Vol. 33, pp. 93-106. 
Rather, R., Hollebeek, L., and Rasoolimanesh, S. (2021). First-time vs. repeat tourism customer engagement, experience, and value co-creation: An empirical investigation. Journal of Travel Research, In press, DOI: 10.1177/0047287521997572.

Rather, R., Hollebeek, L., and Islam, J. (2019). Customer engagement in the tourism sector: The construct, antecedents, and consequences. Service Industries Journal, Vol. 39 No. 7-8, pp. 519540 .

Read, W., Robertson, N., McQuilken, L., and Ferdous, A. (2019). Customer engagement on Twitter: Perceptions of the brand matter. European Journal of Marketing, Vol. 53 No. 9, pp. 1905-1933.

Reinartz, W. and Berkmann, M. (2018). From customer to partner engagement: A conceptualization and typology of engagement in B2B. In: Palmatier, R., Kumar, V., and Harmeling, C. (Eds.), Customer Engagement Marketing, pp. 243-267.

Rey-Martí, A., Ribeiro-Soriano, D., and Palacios-Marqués, D. (2016). A bibliometric analysis of social entrepreneurship. Journal of Business Research, Vol. 69 No. 5, pp. 1651-1655.

Rosado-Pinto, F. and Loureiro, S. (2020). The growing complexity of customer engagement: A systematic review. EuroMed Journal of Business, Vol. 15 No. 2, pp. 167-203.

Roy, S., Shekhar, V., Lassar, W., and Chen, T. (2018). Customer engagement behaviors: The role of service convenience, fairness, and quality. Journal of Retailing and Consumer Services, Vol. 44 No. Sep, pp. 293-304.

Sashi, C. (2012). Customer engagement, buyer-seller relationships, and social media. Management Decision, Vol. 50 No. 2, pp. 253-272.

Sawhney, M., Verona, G., and Prandelli, E. (2005). Collaborating to create: The Internet as a platform for customer engagement in product innovation. Journal of Interactive Marketing, Vol. 19 No. 4, pp. 4-17.

Schivinski, B., Christodoulides, G., and Dabrowski, D. (2016). Measuring consumers' engagement with brand-related social media content: Development and validation of a scale that identifies levels of social-media engagement with brands. Journal of Advertising Research, Vol. 56 No. 1, pp. 64-80.

Sepulcri, L., Wagner, E., and Belchior, C. (2020). Nonprofit branding: A bibliometric analysis. Journal of Product \& Brand Management, Vol. 29 No. 5, pp. 655-673.

Sharma, P., Sadh, A., Billore, A., and Montiani, M. (2021). Investigating brand community engagement and evangelistic tendencies on social media. sharma, In press, DOI: https://doi.org/10.1108/JPBM-01-2020-2705.

Singh, J., Nambisan, S., Bridge, R., and Kai-Uwe Brock, J. (2021). One-voice strategy for customer engagement. Journal of Service Research, Vol. 24 No. 1, pp. 42-65.

Small, H. (1973). Co-citation in the scientific literature: A new measure of the relationship between two documents. Journal of the American Society for Information Science, Vol 24 No. 4, pp. 265-269.

Small, H. (1978). Cited documents as concept symbols. Social Studies of Science, Vol. 8 No. 3, pp. 327-340.

So, K., King, C., and Sparks, B. (2014). Customer engagement with tourism brands: Scale development and validation. Journal of Hospitality \& Tourism Research, Vol. 38 No. 3, pp. 304-329.

So, K., King, C., Sparks, B., and Wang, Y. (2016). The role of customer engagement in building consumer loyalty to tourism brands. Journal of Travel Research, Vol. 55 No. 1, pp. 64-78.

So, K., Li, X., and Kim, H. (2020). A decade of customer engagement research in hospitality and tourism: A systematic review and research agenda. Journal of Hospitality \& Tourism Research, Vol. 44 No. 2, pp. 178-200.

Sprott, D., Czellar, S., and Spangenberg, E. (2009). The importance of a general measure of brand engagement on market behavior: Development and validation of a scale. Journal of Marketing Research, Vol. 46 No. 1, pp. 92-104. 
Stern, B. (2006). What does brand mean? Historical-analysis method and construct definition. Journal of the Academy of Marketing Science, Vol. 34 No. 2, pp. 216-223.

Svantesson, D., Corkery, J., and McCabe, B. (2015). The ghost of rankings: The lasting harmful impact of journal rankings, and what we should do instead. Bond Law Review, Vol. 26 No. 2, pp. 71-85.

Thakur, R. (2019). The moderating role of customer engagement experiences in customer satisfaction-loyalty relationship. European Journal of Marketing, Vol. 53 No. 7, pp. 12781310.

Tuškej, U. and Podnar, K. (2018). Consumers' identification with corporate brands: Brand prestige, anthropomorphism and engagement in social media. Journal of Product \& Brand Management, Vol. 27 No. 1, pp. 3-17.

Van Doorn, J., Lemon, K., Mittal, V., Nass, S., Pick, D., Pirner, P., and Verhoef, P. (2010). Customer engagement behavior: Theoretical foundations and research directions. Journal of Service Research, Vol. 13 No. 3, pp. 253-266.

Van Eck, N. and Waltman, L. (2010). Software survey: VOSviewer. Scientometrics, Vol. 84 No. 2, pp. 523-538.

Van Eck, N. and Waltman, L. (2014). Visualizing bibliometric networks. In: Measuring Scholarly Impact. Springer, pp. 285-320.

Van Eck, N., Waltman, L., Dekker, R., and Van Den Berg, J. (2010). A comparison of two techniques for bibliometric mapping: Multidimensional scaling and VOS. Journal of the American Society for Information Science and Technology, Vol. 61 No. 12, pp. 2405-2416.

Van Nunen, K., Li, J., Reniers, G., and Ponnet, K. (2018). Bibliometric analysis of safety culture research. Safety Science, Vol. 108 No. Oct, pp. 248-258.

Vargo, S. and R. Lusch (2016). Institutions and axioms: an extension and update of servicedominant logic. Journal of the Academy of Marketing Science, Vol. 44, pp. 5-23.

Veloutsou, C. and Ruiz-Mafe, C. (2020). Brands as relationship builders in the virtual world: A bibliometric analysis. Electronic Commerce Research \& Applications, Vol. 39 No. Jan-Feb, 100901.

Venkatesan, R. (2017). Executing on a customer engagement strategy. Journal of the Academy of Marketing Science, Vol. 45, pp. 289-293.

Venkatesan, R., Petersen, J., and Guissoni, L. (2018). Measuring and managing customer engagement value through the customer journey. In: Palmatier, R., Kumar, V., and Harmeling, C. (Eds.), Customer Engagement Marketing, pp. 53-74.

Verhoef, P., Reinartz, W., and Krafft, M. (2010). Customer engagement as a new perspective in customer management. Journal of Service Research, Vol. 13 No. 3, pp. 247-252.

Verleye, K., Gemmel, P., and Rangarajan, D. (2014). Managing engagement behaviors in a network of customers and stakeholders: Evidence from the nursing home sector. Journal of Service Research, Vol. 17 No. 1, pp. 68-84.

Viswanathan, V., Hollebeek, L., Malthouse, E., Maslowska, E., Kim, S., and Xie, W. (2017). The dynamics of consumer engagement with mobile technologies. Service Science, Vol. 9 No. 1, pp. 36-49.

Vivek, S., Beatty, S., and Morgan, R. (2012). Customer engagement: Exploring customer relationships beyond purchase. Journal of Marketing Theory and Practice, Vol. 20 No. 2, pp. 122-146.

Vivek, S., Beatty, S., Dalela, V., and Morgan, R. (2014). A generalized multidimensional scale for measuring customer engagement. Journal of Marketing Theory and Practice, Vol. 22 No. 4, pp. 401-420.

Vogel, R. and Güttel, W. (2013). The dynamic capability view in strategic management: A bibliometric review. International Journal of Management Reviews, Vol. 15 No. 4, pp. 426446. 
Waltman, L., Van Eck, N., and Noyons, E. (2010). A unified approach to mapping and clustering of bibliometric networks. Journal of Informetrics, Vol. 4 No. 4, pp. 629-635.

Wolf, T., Jahn, S., Hammerschmidt, M., and Weiger, W. (2021). Competition versus cooperation: How technology-facilitated social interdependence initiates the self-improvement chain. International Journal of Research in Marketing, In press, DOI: https://doi.org/10.1016/j.ijresmar.2020.06.001.

Xiao, L. and Kumar, V. (2021). Robotics for customer service: A useful complement or an ultimate substitute? Journal of Service Research, Vol. 24 No. 1, pp. 9-29.

Yadav, M. (2010). The decline of conceptual articles and implications for knowledge development. Journal of Marketing, Vol. 74, No. 1, pp. 1-19.

Zagalo, N. (2020). Engagement Design: Designing for Interaction Motivations. Cham (CH): Springer.

Zhao, D. and Strotmann, A. (2008). Evolution of research activities and intellectual influences in information science 1996-2005: Introducing author bibliographic-coupling analysis. Journal of the American Society for Information Science and Technology, Vol. 59 No. 13, pp. 20702086. 